52

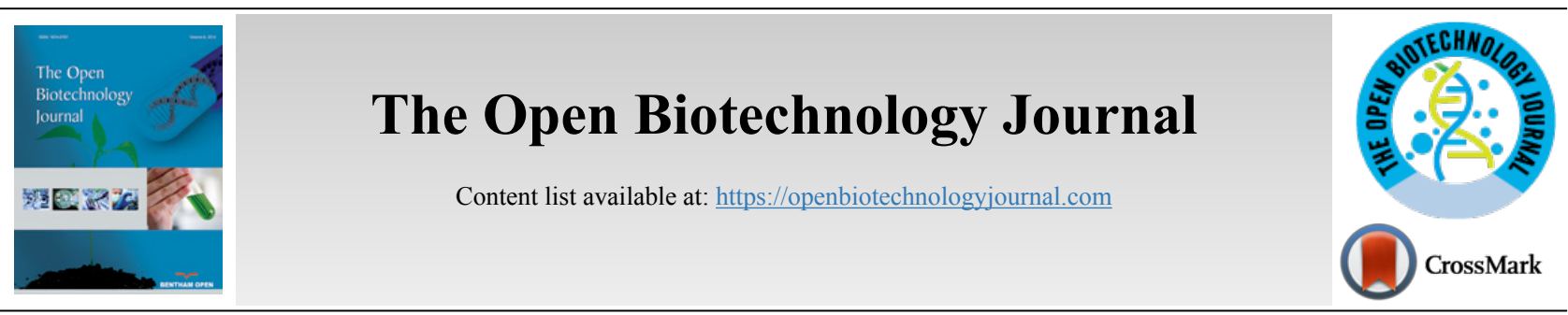

RESEARCH ARTICLE

\title{
Agricultural Wastes For Electricity Generation Using Microbial Fuel Cells
}

\author{
Segundo Rojas Flores ${ }^{1, *}$, Renny Nazario Naveda ${ }^{2}$, Evelyn Abanto Paredes ${ }^{3}$, Jessica Alza Orbegoso ${ }^{3}$, Tiffany Cruz \\ Céspedes $^{3}$, Angie Rodríguez Salvatierra ${ }^{3}$ and Milagros Sánchez Rodríguez ${ }^{3}$
}

${ }^{I}$ Department of Science, Universidad Privada del Norte, Trujillo, Peru

${ }^{2}$ School of Civil Engineering, Cesar Vallejo University, Chimbote, Peru

${ }^{3}$ Department of Environmental Engineering, Universidad Privada del Norte, Trujillo, Peru

\begin{abstract}
:
Background:

Microbial Fuel Cells (MFCs) are promising devices that enable the employment of discarded organic matter, typically gathered around food supply chains, to generate electricity.

Aims:

In this work, low-cost MFCs in the absence of a proton exchange membrane were fabricated.

Methods:

They were built on polyvinyl chloride (PVC) plastic tubes with square acrylic sheets at the ends serving as a framework of anode/cathode chambers and using zinc $(\mathrm{Zn})$ and copper $(\mathrm{Cu})$ metals as electrodes. Tomatoes, onions, and potatoes were used as substrates in MFCs and monitored for 21 days. Variables of interest such as voltage, current, $\mathrm{pH}$, and volume were measured through a $100 \Omega$ resistor.

Results:

The voltage measurements for the onion-based cell showed an upward trend that reaches a peak of 1.01 volts on the last day. Moreover, the greatest current generation was observed in onion cells, in which the current gradually increases from 10.2 to $24.7 \mathrm{~mA}$ on the last day. On the other hand, in all substrates, $\mathrm{pH}$ ranged from 7.5 and 10, which indicates the slightly alkaline behavior of the solutions.

Conclusion:

A reduction in the volume of the substrate was observed during the voltage generation. Finally, during the last day, MFCs were connected in series which allowed for the successful generation of 2.35 volts, and consequently, illumination of LED light.
\end{abstract}

Keywords: Electricity, Microbial Fuel Cell (MFC), Electrodes, Organic matter, Polyvinyl Chloride (PVC), Voltage.

\begin{tabular}{|l|l|l|r}
\hline Article History & Received: November 05, 2019 & Revised: January 06, 2020 & Accepted: February 04, 2020
\end{tabular}

\section{INTRODUCTION}

Electricity has become vital for living around the world, being a necessity for carrying out day-to-day activities. The demand for this energy source is constantly increasing, which translates to a higher fossil fuel demand for its production. Due to the high levels of contamination associated with this, the scientific community is pursuing new methods to produce novel environmental-friendly sources of energy. One of these promising sources is the Microbial Fuel Cells (MFCs) that consist of an anode-cathode chamber separated by a membrane, although the latter is not required in some cells [1].

\footnotetext{
* Address correspondence to this author at Department of Science, Universidad
} Privada del Norte, Trujillo, Peru; E-mail: segundo.rojas.89@gmail.com
At the anode, the bacteria oxidize the organic matter contained in a substrate (fuel) and produce protons and electrons. Protons are diffused from the anode, through a membrane, and to the cathode. There, together with the incoming electrons, they flow through an external circuit. The anode oxidation reaction is balanced by the oxygen reduction in the cathode, where oxygen generally acts as an electron acceptor. In order to accelerate the oxygen reduction reaction, platinum, graphite, among other materials are commonly employed as catalysts. On the other hand, MFCs involve biochemical pathways whose efficiency depends, not only on the operational parameters and design, but also on several biological factors [2]. Indeed, the processes occurring in MFCs, constituted by biocatalyst anodes and chemical cathodes, follow complex interactions addressed by other fields such as electrochemistry, microbiology, materials 
science, transport phenomena, and environmental biotechnology. Furthermore, it has been shown that the design of the compartment structure can drastically affect the power output of the fuel cell [3]. In fact, the cells in a chamber, according to Huang et al. can efficiently remove the nitrate from wastewater, since the interaction between exoelectrogenic and denitrifying bacteria may improve the denitrification activity [4].

Recently, Shrestha et al. studied electricity generation using substandard tomatoes in a microbial electrochemical system [5]. Their cyclic voltammetry results indicate the active role of pigments during electricity production. This fact suggests that its usage can be as effective as purely chemicalbased systems, if not more so. This is even more shocking when you consider that a tomato's nutritional components contribute to the nourishment of the bacteria responsible for redox reactions. More recently, Iigatani et al. studied the efficiency of MFCs based on sweet potato residues [6]. The results indicated that $0.5 \mathrm{~L}$ of the residues in the reactor produces a maximum power of $0.44 \mathrm{~W} / \mathrm{m}^{3}$ after eight days of operation and an optimal $\mathrm{pH}$ of 4.1 . Nonetheless, the $\mathrm{pH}$ may vary depending on the type of potato. These overall results suggest that potato residues may be used as electrolytes in MFCs. Similarly, Divya and Pydi used cashew juice as a substrate for MFCs. Their findings suggest that clarified cashew juice is able to generate up to $0.4 \mathrm{~V}$, with maximum power and current density of $31.58 \mathrm{~mW} / \mathrm{m}^{2}$ and $350 \mathrm{~mA} / \mathrm{m}^{2}$, respectively [7].

Due to the high cost of manufacturing MFCs, some metals are used as substitutes for conventional carbon electrodes [8], graphite [9], activated carbon [10], graphene [11, 12]. Zhu and Logan managed to obtain $00.3 \mathrm{~mA}$ and $2 \mathrm{~mW}$. $\mathrm{m}^{-2}$ of current and power density, respectively, by using anodes of $\mathrm{Cu}$-carbon cloth and $\mathrm{Cu}$-stainless steel of $7 \mathrm{~cm}^{2}$ on MFCs. However, $\mathrm{Cu}$ is highly corrosive and the use of porous materials is highly recommended since they are suitable for bacteria growth [12]. In order to reduce costs in the MFC, Noori et al. showed that using a $\mathrm{Cu}-\mathrm{Sn}$ alloy provides the advantage of increasing the power and voltage density up to $457 \mathrm{~mW} . \mathrm{m}^{-2}$ and $590 \mathrm{mV}$ using wastewater as a substrate, demonstrating that higher power density values can be generated than those described by Zhun and Logan [13]. Whereas, Prasad and Tripathi managed to generate $1.16 \mathrm{~V}$ and $3.01 \mathrm{~mA}$ using copper-zinc electrodes and sediment substrates with the absence of a mediator in a period of 23 days. Results showed that the voltage values increased from the first day of monitoring [14].

MFCs have succeeded in manufacturing a single camera using carbon black electrodes by varying graphene oxide concentrations. They are able to generate $2.642 \mathrm{~mW} \cdot \mathrm{m}^{-2}$ power density for variation of $15: 15$, as well as approximately 0.3 volts for the initial 22 hours of monitoring [15]. The use of stainless steel as electrode has also been reported (with different contact areas of stainless steel) in order to improve power density, with $1.136 \mathrm{~mW} . \mathrm{m}^{-2}$ being generated by stainless steel electrode and steel mesh stainless, so it was also possible to generate voltages of around $760 \mathrm{mV}$. Furthermore, it was found that the power density is inversely proportional to the size of the stainless-steel electrode [16]. On the other hand, Jung and Kim used $3 \mathrm{~cm}$ diameter stainless-steel and carbon felt as cathode and anode respectively, with the stainless steelcarbon felt mesh being the one that showed the lowest electrochemical performance in the long term due to the anodic biofilm that may have grown in stainless steel, managing to generate $555 \mathrm{mV}$; while the MFC with carbon felt generated $569 \mathrm{mV}$. The current densities generated were 1.737 and 2.311 $\mathrm{mW} . \mathrm{m}^{-2}$ for stainless-steel and carbon felt cells, respectively [17]. The performance of the MFCs depends on the microbial communities present in the anode of the cells. Jung and Regan in their MFCs with different substrates found that betaproteobacteria and gammproteobacteria were present in cells fed with oils, while bacillus predominated in cells fed with glucose. Also, the external resistance affects the exoelectrogenic communities that are present in a cell, affecting its performance [18].

In this work, electrical measurements of a single chamber MFC that uses organic matter (potato, tomato, and onion) as a substrate for electricity generation were carried out. Since the processes taking place involved bacteria and degrading microorganisms, agricultural residues (decomposed matter) were used for the purpose of giving it a second utility and, consequently, generating environmentally-friendly electric power.

\section{MATERIALS AND METHODS}

\subsection{Construction of Microbial Fuel Cells}

Microbial fuel cells in the absence of a proton exchange membrane are manufactured (three for each kind of organic waste). A schematic representation of the proposal is shown in Fig. (1). Note that the MFC uses two square acrylics of approximately $144 \mathrm{~cm}^{2}$, in which four holes at the ends of each corner are included. These acrylics serve as lids and support for the cell chamber. The chambers use PVC pipes $(5 \mathrm{~cm}$ in diameter and $10 \mathrm{~cm}$ long), containing circular plates where the cathode is made of Copper $(\mathrm{Cu})$ and anode is made of Zinc ( $\mathrm{Zn}$ ) having $5 \mathrm{~cm}$ diameter and $0.2 \mathrm{~cm}$ thickness at each ends of the pipes. The plates are welded together with copper wire (each wire being approximately $0.3 \mathrm{~cm}$ in diameter) that come out from the two holes located at the ends of the tube. Between the acrylic lids, the pipe is secured with bolts, nuts, and washers. In order to prevent any leakage of the fluid, thermofuse adhesive is applied to the ends of the pipe.

\subsection{Collection of Organic Matter}

Organic residues of onions (Allium cepa), tomatoes (Solanum lycopersicum) and potatoes (Solanum tuberosum) were collected from a local Market (Hermelinda-Trujillo, Perú) and used as substrates (fuel). The residues were crushed and, subsequently, $120 \mathrm{~mL}$ of each substrate (organic residues) was homogenized with a magnetic stirrer and placed inside the cells. Note that the samples were mixed at room temperature $\left(21^{\circ} \mathrm{C} \pm 2^{\circ} \mathrm{C}\right)$.

\subsection{Characterization}

Electrical measurements of the voltage generated during the first seconds of MFCs functioning were recorded through a voltage sensor (differential voltage probe - Venier). On the other hand, the current and voltage produced over the 21 days were measured with a multimeter (Testech, KT-5510), using an 


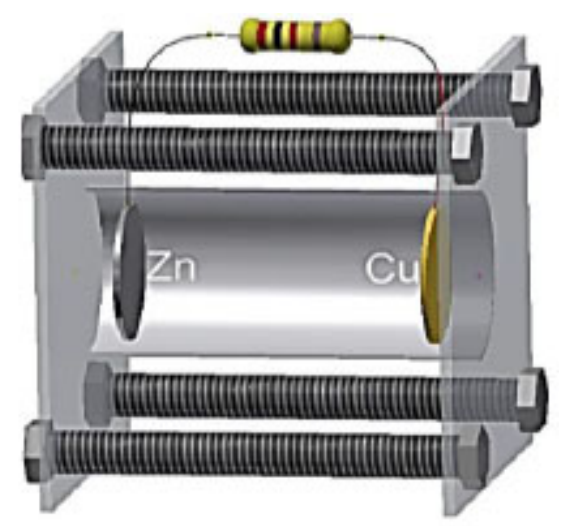

Fig. (1). Schematic representation of a prototype microbial fuel cell.

external resistor of $96.02 \pm 0.01 \Omega$ for the current measurements. In addition, the current density $\left(\mathrm{DC}, \mathrm{mA} / \mathrm{cm}^{2}\right)$ and power density (DP, $\mathrm{mW} / \mathrm{cm}^{2}$ ) were computed by equations $\mathrm{DC}=\mathrm{V} /\left(\mathrm{R}_{\text {ext. }} \mathrm{A}\right)$ and $\mathrm{DP}=\mathrm{V}^{2} /\left(\mathrm{R}_{\text {ext. }} . \mathrm{A}\right)$ [19]. In our system, the cathode area (A) was $19.63 \pm 0.79 \mathrm{~cm}^{2}$, while $\mathrm{V}_{\text {cell }}$, the cell voltage and $\mathrm{R}_{\text {ext }}$, the external resistance. Also, the $\mathrm{pH}$ (multiHQ40D) over the 21 days was recorded at room temperature.

\section{RESULTS AND DISCUSSION}

Fig. (2) shows the average voltage generated during the 21 days of operation. For the tomato substrate, a maximum voltage of 0.974 volts on the sixth day was observed. This value rapidly decreased until eventually reaching 0.757 volts on day 21. In contrast, the onion substrate showed the lowest value, 0.778 volts, in the very early days, which progressively increased up to 1.010 volts on day 21 . Moreover, in the potatobased cells, the voltage decreased until the fourth day, from 0.900 to 0.810 volts. Then, it slightly increased yielding values that oscillate around 0.830 volts.

The observed MFCs power behavior (increase/decrease) may be closely related to the proliferation of microorganisms in the chamber, which in turn depends on the fuel employed [20]. Indeed, these organic residues might present resistance to degradation, which directly affects the growth of microorganisms in the MFCs [21]. Therefore, the voltage variability depends on the availability of the organic wastes, inorganic elements and oligoelements present in the vegetables, the selection and development of microbials, and the average temperature [22]. Furthermore, the microorganisms in vegetables collect the necessary energy for surviving from the oxidation of organic compounds. Hence, these act as biocatalysts that convert the stored energy into electrical power [22]. In the magnesium anodes used as sediment substrates, the possibility of the high energy generated could be due to the corrosion of these types of anodes and the 5 bacterial communities present such as the Uncultured Desulfuromusa clone (16.4\%), Staphylococcus xylosus (15.1\%), Desulfomicrobium baculatum (9.8\%), Desulfobotulus alkaliphilus
(4.8\%) and Escherichia coli (4.6\%) [23].

The results suggest that vegetable residues hold potential to be used as anode substrates in MFCs for power generation [24], given that the sap drawn from plant tissues contains high concentrations of biodegradable compounds such as sugars (mainly sucrose) $(0.2-1 \mathrm{M})$ and amino acids $(0.03-0.6 \mathrm{M})$ that act as biocatalysts in anodic reactions [25 - 27]. Moreover, it has been shown that the ascorbic acid present in the composition of vegetables serves as an electron donor [28], while the minerals, such as Potassium $(\mathrm{K})$ and Magnesium $(\mathrm{Mg})$, as well as the oligoelements, that include Manganese $(\mathrm{Mn})$, Iron $(\mathrm{Fe})$, Copper $(\mathrm{Cu})$, Zinc $(\mathrm{Zn})$ and Molybdenum (Mo), are necessary for the growth and functioning of microorganisms. Many of these act as catalysts in some metabolic reactions related to the bacterial physiology through redox reactions [29].

Fig. (3) shows the average current generated by different MFCs. Clearly, the tomato substrate presents the greatest current $(32.7 \mathrm{~mA})$ during the first two days which drops drastically until the fourth day $(8.7 \mathrm{~mA})$, and from this point, it decreases gradually. In contrast, in onion-based cells, the current increases steadily from $10.2 \mathrm{~mA}$ on the first day to 24.7 $\mathrm{mA}$ on the last day. Concerning the potato-based cells, one can notice a slight decrease from the first day. This behavior might be related to the lower concentration of organic substances, which are responsible for electron conduction [30]. It should be noted that the current generation in MFCs is due to the transfer of electrons produced by the metabolism of present fermentative microorganisms [31]. The generation of electricity is due to the fact that zinc ions (anodic chamber) produce Zinc ions $\left(\mathrm{Zn}^{2+}\right)$ that together with the released electrons travel through the copper wire to the copper electrode (cathode chamber) reacting with the $\mathrm{H}^{+}$ions of the waste generating bio- $\mathrm{H}_{2}$ gas at the same time. The supply of electrons produces electric current due to the potential difference between the two electrodes. The oxidation of organic material is coupled to reduction, according to the following equations [32 - 34]. 


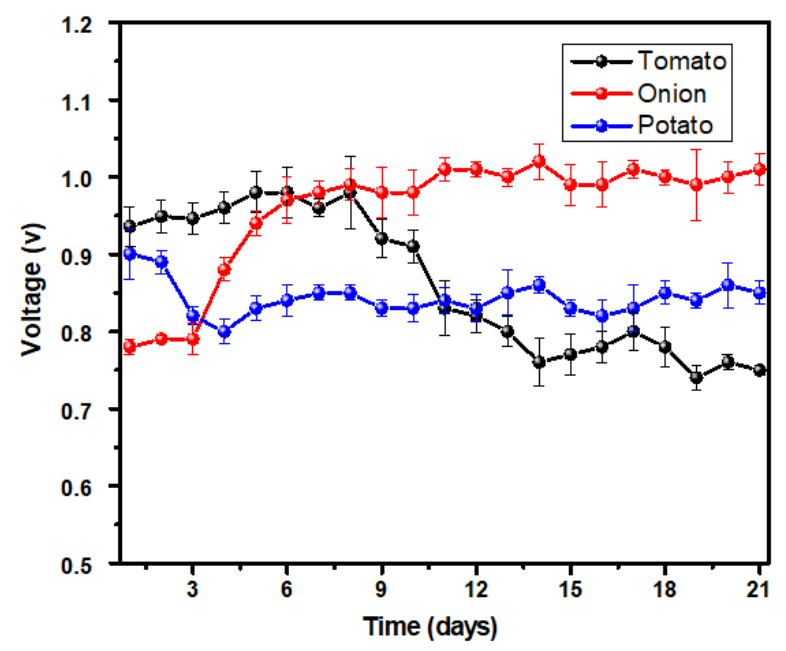

Fig. (2). Average voltage of the MFCs in 21 days of operation.

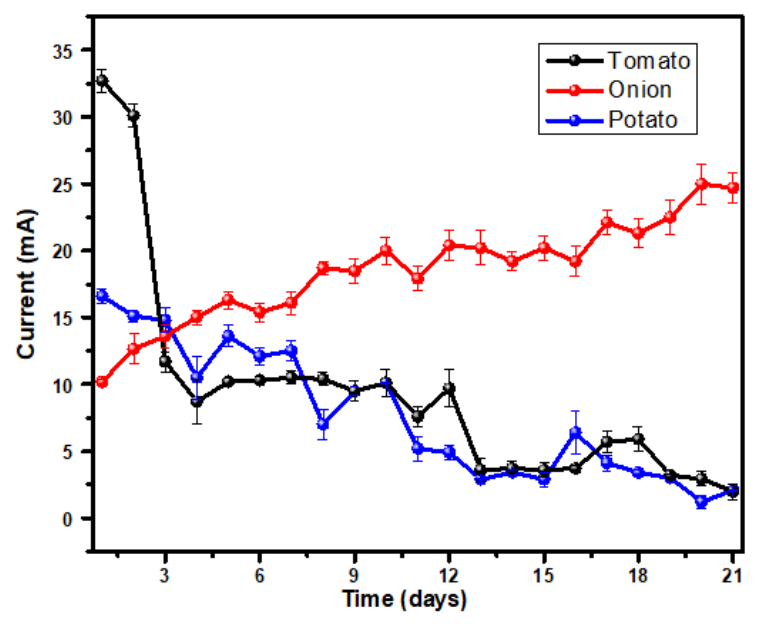

Fig. (3). Average current of the MFCs over 21 days.

$$
\begin{aligned}
& \mathrm{Zn} \rightarrow \mathrm{Zn}^{2+}+2 \mathrm{e}^{-} \text {(anodic reaction) } \\
& 2 \mathrm{H}^{+}+2 \mathrm{e}^{-} \rightarrow \mathrm{H}_{2} \text { (cathodic reaction) } \\
& \mathrm{Zn}+2 \mathrm{H}^{+} \rightarrow \mathrm{Zn}^{2+}+\mathrm{H}_{2} \text { (Overall reaction) }
\end{aligned}
$$

To be thorough, the maximum and minimum values of current density (DC) and power density (DP) for the three substrates, are shown in Table 1 . The maximum values for DP and $\mathrm{DC}$ are $129.9 \mu \mathrm{W} / \mathrm{cm}$ and $128.6 \mu \mathrm{A} / \mathrm{cm}^{2}$ respectively, associated with the onion substrate, while the minimum corresponds to the tomato substrate with $69.7 \mu \mathrm{W} / \mathrm{cm}$ and 94.2 $\mu \mathrm{A} / \mathrm{cm}^{2}$, respectively. This behavior is due to the electrochemical inactivity of some microbe species in the substrate. The competition between them and active microorganisms limits the electrochemical activity until converting into a dominant species [35].

In Fig. (4a), we present the average $\mathrm{pH}$ for different substrates over a period of 21 days. Clearly, cells containing onion show a slightly acidic $\mathrm{pH}$ during the first 8 days, which slightly increases until reaching a neutral character. The $\mathrm{pH}$ in cells containing tomato and potato remains almost constant from the second day until the seventh and eighth day, respectively, with values that fluctuate around 8 and 9.1. After this period, a slight increase, with a subsequent saturation in $\mathrm{pH}$ of 9 and 10, for potato and tomato, respectively, is observed until the $21^{\text {st }}$ day.

Fig. (4b) shows the average substrate volume of each MFC monitored over the 21 day period. The minimum loss of volume is observed in the onion-based cells, which might be related to having the highest voltage generation. By inspecting the potato loss of volume, the greatest among the three organic samples, and its produced power (the lowest of all the samples, Fig. (2)), it is concluded that the greater the loss of volume, the less voltage will be generated over time.

By following the procedure shown in Fig. (5), it is possible 
to generate bioelectricity from organic waste due to exoelectrogenic microorganisms from almost all sources of inorganic or biodegradable organic matter that does not require oxygen for its degradation process [36]. Fig. (5) also depicts the vegetables obtained from organic waste (potato, tomato, and onion) and how they look after being crushed and placed in the microbial fuel cells. Finally, cells (for each substrate) with the highest generated power on day 21 were selected, and a device connected in series was designed. The resulting arrangement managed to reach 2.354 volts, which was enough to illuminate an LED light (yellow).
Other studies already show that electricity can be generated from agricultural waste; for example, the banana and orange peel were used in an MFC obtaining a maximum voltage of 0.67 volts [37]. In the work done by Kondaveeti et al., Citrus Peel Extract was used to obtain a maximum voltage of approximately $0.270 \mathrm{~V}$ [38]. However, data in this work showed that the minimum voltage in the MFC was $0.740 \mathrm{~V}$ for the potato and a maximum of $1.01 \mathrm{~V}$, representing an increase of 10 and $50 \%$ respectively in this system compared to the work done by Toding et al. [37].

Table 1. Current and power density and microbial fuel cell.

\begin{tabular}{|c|c|c|c|c|c|c|}
\hline Substrate & $\mathbf{V}_{\text {min. }}(\mathbf{V})$ & $\mathbf{V}_{\text {max. }}(\mathbf{V})$ & $\mathbf{D P}_{\text {min. }}\left(\boldsymbol{\mu W} / \mathbf{c m}^{2}\right)$ & $\mathbf{D P}_{\max .}\left(\boldsymbol{\mu W} / \mathbf{c m}^{2}\right)$ & $\mathbf{D C}_{\min .}\left(\boldsymbol{\mu A} / \mathbf{c m}^{2}\right)$ & $\mathbf{D C} \mathbf{m a x}_{.}\left(\boldsymbol{\mu A} / \mathbf{c m}^{2}\right)$ \\
\hline Tomato & $0.74 \pm 0.02$ & $0.98 \pm 0.05$ & $290 \pm 27$ & $509 \pm 72$ & $393 \pm 26$ & $520 \pm 47$ \\
\hline Onion & $0.78 \pm 0.01$ & $1.01 \pm 0.02$ & $323 \pm 21$ & $541 \pm 43$ & $414 \pm 22$ & $536 \pm 32$ \\
\hline Potato & $0.80 \pm 0.02$ & $0.89 \pm 0.02$ & $339 \pm 31$ & $420 \pm 36$ & $424 \pm 28$ & $472 \pm 30$ \\
\hline
\end{tabular}
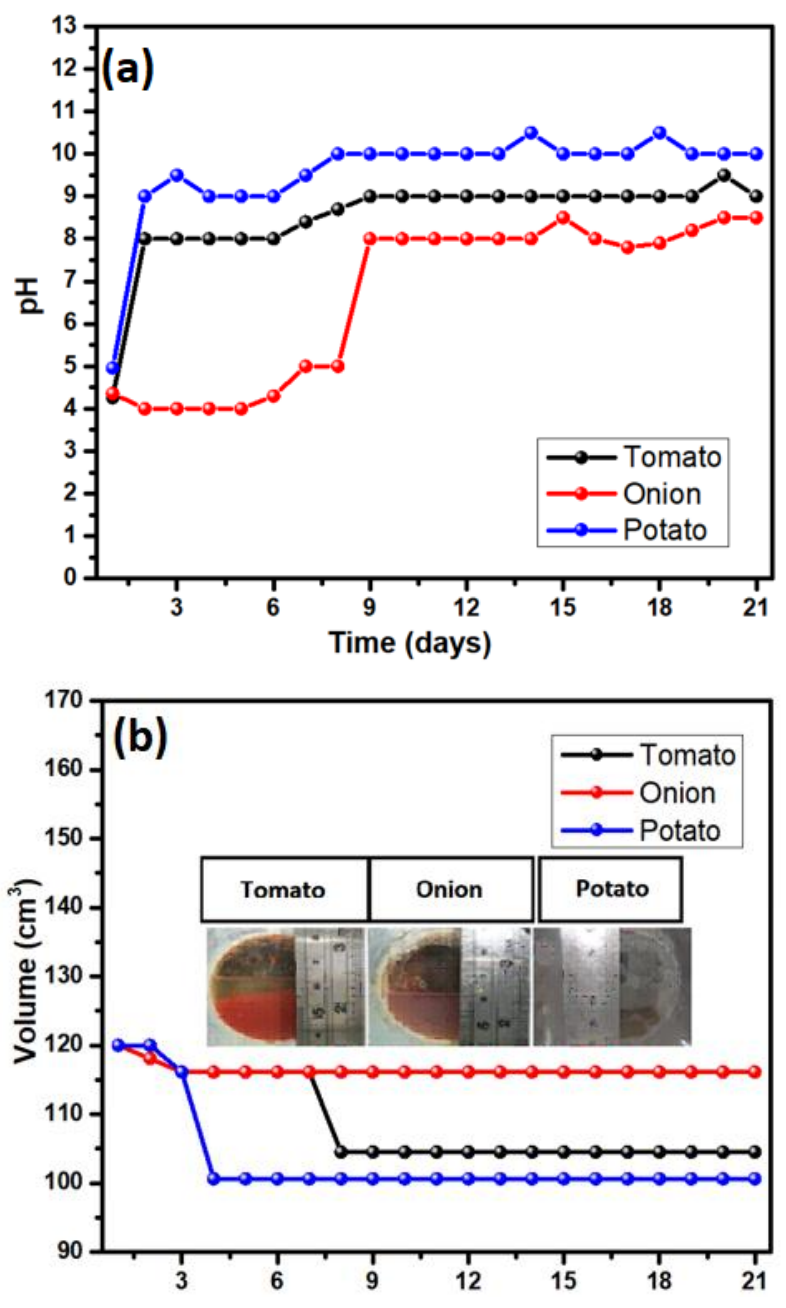

Fig. (4). Time evolution of (a) $\mathrm{pH}$ and (b) volumes in microbial fuel cells. 


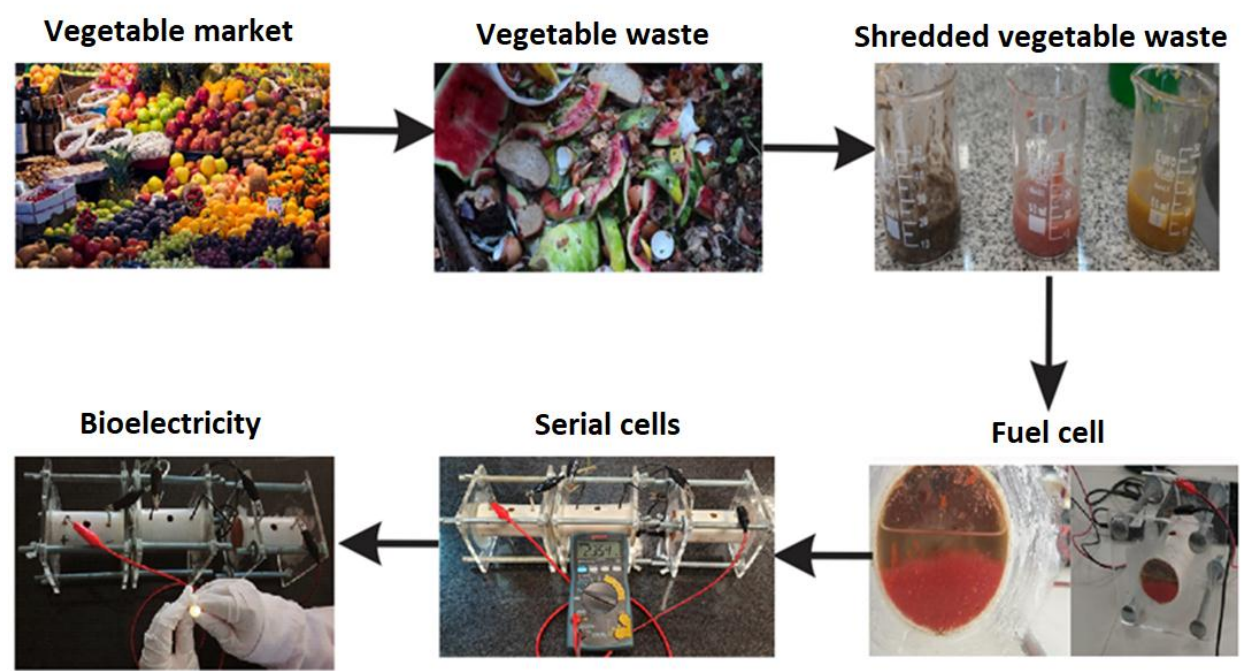

Fig. (5). Outline of bioelectricity production using organic waste.

\section{CONCLUSION}

The potential of tomato, potato, and onion waste as sources of power generation was evaluated, using microbial fuel cells without proton exchange membranes. Onion-based MFCs showed the lowest initial voltage which increased with the passing days, reaching 1.01 volts on the 21 st day, whereas tomato substrate cells presented the highest initial voltage that fell to 0.757 volts on day 21 . Moreover, the current generated by tomato substrate during the first day was $32.7 \mathrm{~mA}$, and it decreased to $4.3 \mathrm{~mA}$ on day 21 . On the other hand, the current of onion-substrate cells increased from 10.2 on the first day until eventually reaching $24.7 \mathrm{~mA}$ on the last day. The $\mathrm{pH}$ measured in MFCs ranged from 7.5 to 10 , suggesting the solutions as being slightly alkaline. Finally, the volumes of the substrates decreased over time. Onion-based cells showed the minimum loss of volume, a factor that may be closely related to its higher voltage generation during the monitoring period. This research provides companies conducting fruit and vegetable businesses an alternative to reuse their products that are unfit for human consumption for the benefit of the company, generating their own electricity and thereby reducing the costs.

\section{ETHICS APPROVAL AND CONSENT TO PARTI- CIPATE}

Not applicable.

\section{HUMAN AND ANIMAL RIGHTS}

Not applicable.

\section{CONSENT FOR PUBLICATION}

Not applicable.

\section{AVAILABILITY OF DATA AND MATERIALS}

Not applicable.
FUNDING

None.

\section{CONFLICT OF INTEREST}

The authors declare no conflict of interest, financial or otherwise.

\section{ACKNOWLEDGEMENTS}

Declared none.

\section{REFERENCES}

[1] De Ramòn A, Salazar M, Ruiz D, Greenman J. Modelando la recolección de energía a partir de celdas de combustible microbianas basadas en cerámica utilizando un enfoque de lógica difusa Elsevier, 2512019 .https://www.sciencedirect.com/science/article/pii/S030626 19930995X

[2] Gadkari S, Shemfe M, Sadhukhan J. Microbial fuel cells: A fast converging dynamic model for assessing system performance based on bioanode kinetics. Int J Hydrog Energy 2019; 44(29): 15377-86.

[3] Anthony S, Kathryn W, Dale B, Craig B. Microbial fuel cells: An overview of current technology. Renew Sustain Energy Rev 2019; 60-81.

[4] Huang H, Sheng S, Li F, Mao Z, Lin Z, Cen K. Mejora de la actividad de desnitrificación por exoelectrógenos en células de combustible microbiano de cátodo de aire de cámara única Elsevier, 2019.

[5] Shrestha N, Fogg A, Wilder J, Franco D, Komisar S, Gadhamshetty V. Electricity generation from defective tomatoes. Bioelectrochemistry 2016; 112: 67-76.

[http://dx.doi.org/10.1016/j.bioelechem.2016.07.005]

[PMID: 27474917]

[6] Iigatani R, Ito T, Watanabe F, Nagamine M, Suzuki Y, Inoue K. La generación de electricidad a partir de residuos de patata-shochu dulce utilizando células de combustible microbianas Elsevier, 2019.

[7] Divya A. Anacardo zumo de manzana como sustrato para la célula de combustible microbiana. Elservier 2019.

[8] Meng Y, Young TM, Liu P, Contescu CI, Huang B, Wang S. Ultralight carbon aerogel from nanocellulose as a highly selective oil absorption material. Cellulose 2015; 22(1): 435-47. [http://dx.doi.org/10.1007/s10570-014-0519-5]

[9] Erable B, Byrne N, Etcheverry L, Achouak W, Bergel A. Single medium microbial fuel cell: stainless steel and graphite electrode materials select bacterial communities resulting in opposite electrocatalytic activities. Int J Hydrogen Energy 2017; 42(41): 26059-67. 
[http://dx.doi.org/10.1016/j.ijhydene.2017.08.178]

[10] Mayer F, Stöckl M, Krieg T, Mangold KM, Holtmann D. Adsorption of Shewanellaoneidensis MR1 to the electrode material activated carbon fabric. J Chem Technol Biotechnol 2018; 93(10): 3000-10. [http://dx.doi.org/10.1002/jctb.5658]

[11] Phiri J, Johansson LS, Gane P, Maloney T. A comparative study of mechanical, thermal and electrical properties of graphene-, graphene oxide-and reduced graphene oxide-doped microfibrillated cellulose nanocomposites. Compos, Part B Eng 2018; 147: 104-13. [http://dx.doi.org/10.1016/j.compositesb.2018.04.018]

[12] Zhu X, Logan BE. Copper anode corrosion affects power generation in microbial fuel cells. J Chem Technol Biotechnol 2014; 89(3): 471-4. [http://dx.doi.org/10.1002/jctb.4156]

[13] Noori MT, Bhowmick GD, Tiwari BR, Ghangrekar MM, Mukhrejee $\mathrm{CK}$. Application of low-cost $\mathrm{Cu}-\mathrm{Sn}$ bimetal alloy as oxygen reduction reaction catalyst for improving performance of the microbial fuel cell. MRS Adv 2018; 3(13): 663-8.

[http://dx.doi.org/10.1557/adv.2018.163]

[14] Prasad J, Tripathi RK. Maximum electricity generation from low cost sediment microbial fuel cell using copper and zinc electrodes. 2017 International Conference on Information, Communication, Instrumentation and Control (ICICIC). [http://dx.doi.org/10.1109/ICOMICON.2017.8279078]

[15] Koo B, Lee SM, Oh SE, et al. Addition of reduced graphene oxide to an activated-carbon cathode increases electrical power generation of a microbial fuel cell by enhancing cathodic performance. Electrochim Acta 2019; 297: 613-22.

[http://dx.doi.org/10.1016/j.electacta.2018.12.024]

[16] Nam T, Son S, Kim E, et al. Improved structures of stainless steel current collector increase power generation of microbial fuel cells by decreasing cathodic charge transfer impedance. Environ Eng Res 2018; 23(4): 383-9.

[http://dx.doi.org/10.4491/eer.2017.171]

[17] Jung SP, Kim E, Koo B. Effects of wire-type and mesh-type anode current collectors on performance and electrochemistry of microbial fuel cells. Chemosphere 2018; 209: 542-50

[http://dx.doi.org/10.1016/j.chemosphere.2018.06.070] [PMID: 29945047]

[18] Jung S, Regan JM. Influence of external resistance on electrogenesis, methanogenesis, and anode prokaryotic communities in microbial fuel cells. Appl Environ Microbiol 2011; 77(2): 564-71.

[http://dx.doi.org/10.1128/AEM.01392-10] [PMID: 21075886]

[19] Yan Z, Wang M, Huang B, Liu R, Zhao J. Graphene supported Pt-Co alloy nanoparticles as cathode catalyst for microbial fuel cells. Int $\mathrm{J}$ Electrochem Sci 2013; 8(1): 149-58.

[20] Goud R K, Babu P S, Mohan S V. Canteen based composite food waste as potential anodic fuel for bioelectricity generation in single chambered Microbial Fuel Cell (MFC): bio-electrochemical evaluation under increasing substrate loading condition. Int J Hydrog Energy 2011; 36(10): 6210-8.

[21] Pant D, Singh A, Van Bogaert G, et al. Bioelectrochemical systems (BES) for sustainable energy production and product recovery from organic wastes and industrial wastewaters. RSC Adv 2012; 2(4): 1248-63.

[http://dx.doi.org/10.1039/C1RA00839K]

[22] Logroño WN, Echeverría MM, Recalde CG, Graziani P. Bioconversion of organic solid wastes with soils from the Amazonian and high Andean regions of Ecuador in single chamber microbial fuel cells. Inf Tecnol 2015; 26(2)

23] Jung SP, Yoon MH, Lee SM, Oh SE, Kang H, Yang JK. Powe generation and anode bacterial community compositions of sediment fuel cells differing in anode materials and carbon sources. Int J Electrochem Sci 2014; 9(1): 315-26.

[24] Schröder U. Anodic electron transfer mechanisms in microbial fuel cells and their energy efficiency. Phys Chem Chem Phys 2007; 9(21): 2619-29.

[http://dx.doi.org/10.1039/B703627M] [PMID: 17627307]

[25] Amiard W, Morvan-Bertrand A, Cliquet JB, et al. Carbohydrate andamino acid composition in phloem sap of LoliumperenneL.before and after defoliation. Can Bot 2004; 82: 1594-601. [http://dx.doi.org/10.1139/b04-117]

26] Fukumorita T, Chino M. Sugar, amino-acid and inorganic contents in rice phloem sap. Plant Cell Physiol 1982; 23: 273-83.

[27] Girousse C, Bonnemain JL, Delrot S, Bournoville R. Sugar and aminoacid-composition of phloem sap ofmedicago-sativa - a comparativestudy of 2 collectingmethods. Plant Physiol Biochem 1991; 29: 41-8.

[28] Hughes M, Poole R. Metal speciation and microbial growth-the hard (and soft) facts. J Gen Microbiol 1991; 137: 725-34.

[http://dx.doi.org/10.1099/00221287-137-4-725]

[29] Kader AA, Stevens LLMMA, Albrigltt-Holton M. Composition and flavor quality of fresh market tomatoes as influenced by some postharvest handling procedures. Am Soc Hortic Sci 1978; 3: 6e13.

[30] Nayak JK, Ghosh UK. An innovative mixotrophic approach of distillery spent wash with sewage wastewater for biodegradation and bioelectricity generation using microbial fuel cell. J Water Process Eng 2018; 23: 306-13

[http://dx.doi.org/10.1016/j.jwpe.2018.04.003]

[31] Richter H, McCarthy K, Nevin KP, Johnson JP, Rotello VM, Lovley DR. Electricity generation by Geobacter sulfurreducens attached to gold electrodes. Langmuir 2008; 24(8): 4376-9. [http://dx.doi.org/10.1021/la703469y] [PMID: 18303924

[32] Khan AM, Obaid M. Comparative bioelectricity generation from waste citrus fruit using a galvanic cell, fuel cell and microbial fuel cell. J Energy South Afr 2015; 26(3): 90-9. [http://dx.doi.org/10.17159/2413-3051/2015/v26i3a2143]

33] Heijne AT, Liu F, Weijden RV, Weijma J, Buisman CJ, Hamelers HV. Copper recovery combined with electricity production in a microbial fuel cell. Environ Sci Technol 2010; 44(11): 4376-81. [http://dx.doi.org/10.1021/es100526g] [PMID: 20462261]

[34] Radi MH, Al-Fetlawi HAZ. Influence of Electrodes Characteristics on The Performance of a Microbial Fuel Cell. J Uni Babylon 2017; 25(4): 1328-38.

[35] Ismail ZZ, Radeef AY. Biotreatment of Actual Potato Chips Processing 2018.

[36] Logan BE, Rabaey K. Conversion of wastes into bioelectricity and chemicals by using microbial electrochemical technologies. Science 2012; 337(6095): 686-90.

[http://dx.doi.org/10.1126/science.1217412] [PMID: 22879507]

[37] Toding OSL, Virginia C, Suhartini S. Conversion banana and orange peel waste into electricity using microbial fuel cell. IOP Conference Series: Earth and Environmental Science Vol. 2092018; : 012049. IOP Publishing

[http://dx.doi.org/10.1088/1755-1315/209/1/012049]

[38] Kondaveeti S, Mohanakrishna G, Kumar A, Lai C, Lee JK, Kalia VC. Exploitation of citrus peel extract as a feedstock for power generation in Microbial Fuel Cell (MFC). Indian J Microbiol 2019; 59(4): 476-81. [http://dx.doi.org/10.1007/s12088-019-00829-7] [PMID: 31762511]

\section{(c) 2020 Flores et al.}

This is an open access article distributed under the terms of the Creative Commons Attribution 4.0 International Public License (CC-BY 4.0), a copy of which is available at: (https://creativecommons.org/licenses/by/4.0/legalcode). This license permits unrestricted use, distribution, and reproduction in any medium, provided the original author and source are credited. 